\title{
Toward a geographical socionarratology
}

https://doi.org/10.1515/fns-2018-0019

\begin{abstract}
Narrative space has attracted increasing attention in recent years, yet this attention only sporadically falls on narrative geography. In this article, I consider the possibility of geographical socionarratology and suggest that a geographical approach is able to enrich the perspective of socionarratology. Correspondingly, a social perspective can enhance the interpretative power of geography. Drawing from Jerome Bruner's $(1990,1991)$ narrative theory, "canonicity and breach" as well as Reinhart Kosellek's (2004) theory on the "existential pair" of expectation and experience, I argue that different geographical locations embody different expectations, emotions, and perspectives of action for characters and storytellers. The contradictory play of contested and conflicting expectations is analyzed more closely by reading Ian McEwan's The Children Act (2014), a novel portraying competing family cultures and ethical principles. By connecting geography to expectations, I argue, the interpretative advantages of geography in narratology increase substantially.
\end{abstract}

Keywords: geography, socionarratology, expectation, canonicity, profession

Socionarratology has been understood in a number of contradictory ways in recent literature. ${ }^{1}$ David Herman (1999: 218), who coined the term, quite straightforwardly meant the incorporation of the Labovian sociolinguistic study of narration within the traditions of narratology, thus following the example set by Monika Fludernik (1996). Ten years later, in Basic Elements of Narrative, Herman (2009) dropped the term socionarratology, but integrated a wider range of socially oriented studies into his model, including Jerome Bruner's work, ethnomethodological conversation analysis, and positioning analysis. The sociologist Arthur W. Frank (2010: 12-13) in turn has adopted Herman's concept, but uses it to refer to all kinds of sociologically oriented studies of narrative, and in doing so, ignores narratological thought entirely. Departing from Herman's aim of building a cover-

1 I am grateful to the Academy of Finland research project (285144) The Literary in Life: Exploring the Boundaries between Literature and the Everyday for supporting my work for this article.

*Corresponding author: Matti Hyvärinen, University of Tampere, Finland,

E-Mail: Matti.k.hyvarinen@uta.fi 
ing model and Frank's disregard for narratological theory, my proposal is to study more systematically the areas potentially shared by narratology and the social research on narratives. Taking geography seriously offers one important way to proceed into incorporating the "social" more profoundly in narratological analysis, and this provides an entirely new resource for socionarratology.

\section{Geography and expectations}

Franco Moretti (1999) has already demonstrated the political and social relevance of geography using nineteenth-century novels. In his study, Moretti focused on the quantitative analysis of large masses of novels and the major moves of their protagonists. With his substantial corpus, Moretti was able to discuss the economic undercurrents of nineteenth-century novels more persuasively than the qualitative analysis of contemporary novels does. The primary material for my article is Ian McEwan's (2014) novel The Children Act (hereafter TCA), which I read with the help of Jerome Bruner's theory of "canonicity and breach" (Bruner 1990, 1991; Herman 2009; Hyvärinen 2016). According to Bruner, everyday narratives are told only when some canonical expectations of the particular culture are broken. Without discarding the critical difference between fiction and non-fiction, I nevertheless argue for the relevance of Bruner's theory in reading fiction. In particular, the theory foregrounds the way cultural and social expectations precede and condition experientiality (Fludernik 1996), yet it remains partly problematic in not properly addressing the problem of contested canonicities - that is, competing and conflicting cultural expectations. When understood as the central source of narrativity, experientiality promotes a predominantly cognitive approach to narratology. Following the historian Reinhart Koselleck (2004), I suggest that the "existential pair" of expectation and experience should replace the one-sided focus on experience (Hyvärinen 2016; Pickering 2004). As Joan Scott (1998: 69) has argued, it is vital to ask what preceded the particular experiences, and why people had precisely these experiences. Expectations, in turn, are socially, culturally, and historically construed, thus justifying the perspective of socionarratology. Expectations also render geography relevant, as the conflicting cultural expectations are often closely linked to particular locations. What is more, geographical locations condition characters' personal emotions and expectations, as I will argue in this article.

Over the last twenty years, McEwan has published a series of novels that portray core middle-class professions, featuring, for example, a neuro-surgeon (Saturday, McEwan 2005), a physicist (Solar, McEwan 2010), a novelist (Atonement, McEwan 2001), a composer, and a journalist (Amsterdam, McEwan 1998). 
TCA complements the list with the leading High Court Judge Fiona Maye, whose job is to preside over the family court and decide on various - often agonizing cases concerning child welfare. In this article, the "social" aspect of the analysis is focused primarily on the theme of the profession, the canonicity within the legal profession, and the transgressions of professional expectations.

When cultural expectations about an acceptable life course seriously collide in contemporary societies, it is typically the law courts that have to decide on the limits of acceptable conduct. In the novel, the maps of London, the United Kingdom, and the world are dotted by competing family cultures and values. The Children Act, a British law from 1989, ordains that, when a court of law decides on a child's upbringing, the "paramount issue" must be the "child's welfare." In the novel, the judge faces a paradox of the liberal state: she needs to be impartial and neutral as regards all the religious and cultural convictions of the families, yet she needs to reason her decision by privileging the culturally accepted understanding of the child's welfare. As a result, the court is a meeting place for different cultural and religious expectations and, consequently, a meeting place for different corners of the city. Moreover, the legal profession itself keeps maintaining its own cultural canonicities. In England, this has a particularly strong geographical aspect because of the system of Inns of Court (this is discussed more thoroughly in Section 3).

In addition to the involving and troubling law cases, Fiona Maye has to deal with a marital crisis and the threat of separation, since her husband Jack curtly announces at the beginning of the novel that he would like to start a relationship with a younger colleague. This not only implies that Fiona is in a state of exceptional vulnerability while encountering the novel's decisive law case; it also means that she has lost her safe place, the mental security and peace of her home at Gray's Inn. She has lost her solid geographical footing as well as trust in the expected course of her personal life. Here, the novel resembles contemporary crime stories, wherein the detective (as the professional) seldom remains untouched by the very problems he or she is investigating. The model of Hercule Poirot at work with his "little grey cells" within his own pristine world has been lost for good; the life of the professional is affected by the problems under investigation.

\section{Dynamic space and geography}

Paul Ricoeur $(1981,1984)$ probably deserves the greatest credit for radicalizing the understanding of narrative time and freeing time from the straightjacket of serial chronology. In the wake of the realization of the complexities of time, however, 
the aspect of space has received a diminished amount of attention (Friedman 2005: 192). Michel de Certeau's (1984: 117) distinction between the ordered "place" and historically and socially charged "space" has, nevertheless, inspired students of narrative to interpret space in more dynamic terms. Mike Baynham (2003, 2015), Anna De Fina (2003), and Alexandra Georgakopoulou (2003), for example, have questioned the static role of "orientation" in William Labov's (1972) theory of oral narrative. The problem, the writers say, lies in understanding space only as a static "backdrop" - a location where the action takes place. The classical Greek adventure novel, as Bakhtin $(1981,100)$ puts it, might be the uttermost example of such a downplaying of the role of the place, because "what happened in Babylon could just as well happen in Egypt or Byzantium and vice versa." In contrast to this understanding of space as a passive container, Baynham (2003: 352) urges us to ask, firstly, how spaces are "understood as semiotic resources," and secondly, how "space/time orientation [can be] understood as constitutive of narrative action." Georgakopoulou suggests the useful concept of "space affordances," foregrounding the way different spaces are conducive to different actions.

Marie-Laure Ryan et al. (2016: 1) similarly criticize the traditional understanding of space as a "backdrop of plot." They argue that space can also be, for example, "a focus of attention, a bearer of symbolic meaning, an object of emotional investment." Despite this point of departure, the authors remain rather unspecific in elaborating the ways space and geography can interact more actively with the events of the narrative. The authors point out, in a useful way, how "the use of place names borrowed from real-world geography situate the story in a specific spatial setting" (Ryan et al. 2016: 19). However, the use of these proper names tends to remain too narrowly cognitivist, because "the referents of actual place names enter the storyworld with most of their real-world properties; readers will imagine Italy as sunny, England as foggy and industrialized, Belfast as the Protestant rival of Catholic Dublin" (2016: 20). Instead of focusing primarily on readers' prototypical reactions to place names, I emphasize here the way Fiona Maye, the protagonist of $T C A$, perceives, feels, and is influenced by geographical places - that is, has her embodied existence in space. The interaction between geography and the thoughts and actions of the characters should thus be a central issue for geographical narratology. The perspective of the authorial audience, rather than of the prototypical reader, offers more nuanced ways of reading the cultural importance of places (Rabinowitz 1987: 29-32; Phelan 2007).

The enhanced awareness of the role of space has helped to grant "a constitutive, indeed performative role for space/time orientation in narrative" (Baynham 2015: 137), yet most of the discussion on space has an essential limitation from the perspective of this article. "Space" is typically discussed in rather abstract, 
cognitive, or primarily deictic terms, without a particular interest in geography (e.g. Herman 2001; Friedman 2005; Perrino 2015). For the purposes of this article, I define geography as the use of proper names of places that tune characters' thoughts and actions and mobilize shared and contested cultural connotations. "Every story is a travel story - a spatial practice," maintains de Certeau (1984: 115). That may be so, but not nearly equally in every story. For example, McEwan's The Cement Garden (1978) is principally set within one house and its garden, without much need for anchoring the story to any actual or fictional locations beyond the garden. For this reason, not every story is a geographical story, but TCA certainly is a geographical story: it is both a travel story and a spatial practice.

\section{At Gray's Inn}

The novel begins and ends at Gray's Inn, in the district of Holborn in central London. Holborn is inconspicuously located between the financial center of the City, the artistically well-known Bloomsbury, and the nightlife centers of Soho and Covent Garden. There are dozens of books on London districts and their histories, yet most of them tend to ignore Holborn completely. We know that it is a rather mixed area in terms of class and race. The area is made up of housing, offices, universities, hospitals, and - importantly for TCA - several law-related institutions. Gray's Inn, Lincoln Inn, and the High Courts of Law give a particular character to the district, but they by no means dominate the whole area. Gray's Inn itself is a very peculiar British institution.

Gray's Inn is one of the four Inns of Court which have the exclusive right to call men and women to the Bar of England and Wales. The Inn exists to support, educate and develop its student barrister members and to provide continuing professional development to its qualified barrister members in accordance with its historic traditions. (Gray’s Inn 2018)

The profession's process of education and qualification reminds one more of the medieval guild system than the modus operandi of a modern welfare state. It is the very powerful stronghold of a powerful profession, and it features lodgings for members, a chapel, and rich cultural and educational programs for members and invited audiences. In addition to living for years in Holborn and Bloomsbury, Charles Dickens also served as a clerk at Gray's Inn in 1827-1828.

The records of the Inn begin in the mid-sixteenth century, but the reason why the lawyers' institutions originally came to Holborn is considered to be "a decree of Henry III, dated 2 December 1234, that no body providing legal education should be located in the City of London," presumably because of earlier corrup- 
tion by the legal profession (Gray's Inn 2018). Holborn was conveniently near the border of the City, close to Westminster, and a relatively empty space at the time. This prestigious, partly conflicting history is not very much explored in the novel, though some of the "spatial practices" (Lefebvre 1991: 38) of the Inn are gradually revealed. This observation leads to some methodological concerns. In line with Bruner's theory, the characters do not think about or foreground the habitual, usual features of their environment. Therefore, I recommend visiting the relevant places if possible. In the present study, this especially concerns "Fiona's walk," discussed later in detail, a walk I retraced while taking photographs along the way. The purpose of the exercise is never to efface the fictionality of the novel; in contrast, it elevates the salience of the entirely invented places.

The geography of the novel, as discussed earlier, cannot be a narrow question of orientation regarding where the action takes place. On another level, the families in Judge Maye's cases have their origins, homes, and countries to flee to in order to escape justice, and these typically appear in Fiona's mind representations and legal drafts. In the first case, the divorcing Orthodox Jewish parents disputing the nature of their daughter's education "were from the tight folds of the strictly observant Haredi community in north London" (McEwan 2014: 10). These are Fiona Maye's thoughts, sitting at home at Gray's Inn, reading the documents of the case, contemplating the "tight folds of the strictly observant" community and locating them in north London. David Harvey (1989: 218-221) makes somewhat similar distinctions and suggests the study of material spatial practices, representations of space, and spaces of representations (cf. Lefebvre 1991: 38-39). While looking at the material, geographical practices, I will follow such material phenomena as transfers between places, railings, barriers and bridges connecting locations, as well as the mental processing of places. As Ryan et al. (2016: 21) note, movement is the phenomenon that "facilitates the conceptualization of the intimate connection between space and time.” McEwan's novel portrays three emotionally and professionally different travels worthy of closer analysis.

\section{Problems from afar}

The central organizing geographical division in TCA is between the safe, liberal, and professional environs of Gray's Inn and the problematic, religious, and conservative - or too ramshackle - areas further away from Holborn. Fiona's first travel, a version of her daily walk, covers most of what I call the Gray's Inn orbit. A few other nearby locations extend the domestic network: tennis in Mecklenburgh Square, dinner in Clerkenwell, "warmed pain aux raisins from Lamb's 
Conduit Street” (McEwan 2014: 181) for Saturday mornings. Outside this homelike circle, Fiona's childhood home in the conservative, middle-class Finchley in north London had been "her mother's airless polished domain" (McEwan 2014:151). The Haredi Jewish girls live in Stamford Hill, five miles northeast from Gray's Inn. Jack's potential lover, Melanie, naturally also lives further away, near Muswell Hill, north London. Similarly, a Moroccan businessman takes his daughter from his English wife to Rabat and beyond the jurisdiction of British law (McEwan 2014: 5).

In Fiona's most nightmarish case, the Siamese twins Matthew and Mark have Jamaican and Scottish parents "living in a village on Jamaica's north coast" (McEwan 2014: 26-32). The twins are expected to die presently due to fatal deficiencies in Matthew's vital organs. The medical authorities draw on utilitarian ethics and want to save Mark with an operation that would eventually kill Matthew. The parents do not approve of this "murder" of Matthew and are prepared for the death of both twins if that is God's will. The Roman Catholic Archbishop of Westminster supports their decision and advises the authorities "not to interfere with God's purpose" (McEwan 2014: 30).

Any decision in the case will result, in one way or the other, in the death of a child. The utilitarian decision to save Mark ultimately threatens to leave him with parents and a community that are not entirely happy with his existence, and to forever mark him with the death of his twin brother. In the dispute, canonical expectations about the significance of "saving a life" break down into fiercely competing interpretations. What is more, the protagonist can no longer reach a decision within the liberal calm of the High Court or Gray's Inn, since “doctors, priests, television and radio hosts, newspaper columnists, colleagues, relations, taxi drivers, the nation at large had a view" (McEwan 2014: 27). This is indeed the process of generating shared expectations in the face of competing canonicities. The perfect judge should hear all these voices and recognize them in the resolution while overcoming pure cultural relativism and setting credible limits on canonicity. The very publicity of the case brings about a professional and geographical border crossing, and Fiona cannot solve the case calmly at a controlled professional distance without embodied and existential anxiety. This conflict over canonicity becomes highly tellable as it becomes, in the novel, a causal force shaking Fiona's marriage by rendering her more distant and evasive, even with Jack.

The day after learning about Jack's adulterous plans, Fiona takes her circular walk to the Royal Courts of Law in the Strand, and back around Kingsway and Theobald's Road. From the beginning, it is "her usual route," and she hardly notices what is around her. She tries to resist immersion in her marital situation, and so resorts to music and plays "to her inner ear a piece she had learned by 
heart” (McEwan 2014: 45). Traffic and nature reignite her inner tumult, and soon she returns to musing on Jack and her own situation. She forces herself "back to her partita," yet a thought about Bach and his twenty children diverts her mind to her own childlessness (McEwan 2014: 47).

The narrator recounts Fiona's route from Chancery Lane through a passage to Lincoln's Inn and New Square. Because of her ruminations and attempts to focus on music, she barely registers anything. As she passes Wildy's bookshop, she is "untempted by the law books in the window display" (McEwan 2014: 50). So familiar is the walk that she completes it as if on autopilot. At her office, however, she soon comes to: she phones the local locksmith and asks that the locks to the apartment she shares with Jack be changed, with the new keys delivered to the Strand (McEwan 2014: 52). In terms of Harvey (1989: 220-221), this move changes the "domination and control of space" by making their joint home a closed space to Jack. She protects her peace at home, yet at a considerable price. Soon "she was already wondering at her ridiculous transgression, obstructing her husband from rightful access, one of the clichés of marital breakdown, one that an instructing solicitor would advise a client - generally the wife - against in the absence of a court order" (McEwan 2014: 53). An embarrassing transgression, indeed, because if Jack were to take legal action and sue her for the obstruction, she would be professionally ridiculed, and precisely within her own specialty. How could she have acted so stupidly?

The tide of the transgression was already rising during the walk, while thinking of the "sullen and rebellious" Thames and the "vigorously undeterred" traffic on High Holborn (McEwan 2014: 46). Barring Jack's access may be interpreted in a number of different ways, ranging from understanding it as a mere emotional outburst to seeing it as Fiona demonstrating her own seriousness in the dispute; nevertheless, there is an element of paradoxical trust in Jack. Even in the middle of the crisis, while entertaining all kinds of paranoid thoughts about him, Fiona seems somehow to believe that Jack is not a person who would immediately resort to legal action against her.

In the evening, in order to delay her homecoming, she takes a circuitous route by walking west on the Strand to Aldwych and then north on Kingsway. Later, on High Holborn, she turns again west and walks north toward Theobald's Road. By taking a detour, she further postpones the forthcoming encounter with Jack, and gives herself more time with additional geographic distance. She is still mulling over her situation most of the time, but she is no longer as hermetically closed as she was in the morning. She sees a key-cutting shop and remembers her lockchange operation with some remorse, expecting a shouting Jack at the door. Among the all too familiar things she does not think about during her walk are the high walls and iron railings that separate the Inns and the public spaces around 
them. Fiona is oblivious to the homeless people sleeping on the street corners just opposite the Royal Courts of Law. The familiar geography and places do not actively participate in her actions and thoughts; they rather provide her with space to think and delay her inevitable return home.

\section{Transgressing the borders: The hospital}

The critical law case in the novel focuses on a forced transfusion to a slightly under-age boy, Adam Henry, from a family of committed Jehovah's Witnesses. Adam suffers from leukemia, and the representatives of the hospital argue that the vital treatments he needs will not work without a transfusion. Again, this case is urgent, widely publicized, and apparently a matter of life and death. Can Fiona overrule Adam's own will and the family's intense, religious conviction?

As in all the narrated cases, Fiona eventually decides against particular demands based on religious faith. In Adam's case, however, she departs from her normal procedure of decision-making. After hearing both parties, Fiona orders a suspension of the proceedings in order to talk to Adam personally. She does so despite the previous day reasoning that "visiting the hospital was a sentimental whim. She dismissed the idea..." (McEwan 2014: 37). Her irresolution concerns the limits of her profession and the proper conduct expected in her position. While sitting in a taxi, she still wonders if this was "about a woman on the edge of a crack-up making a sentimental error of professional judgement," or something that truly concerned the case. She never receives a definitive answer to her question, but the decision to visit the hospital leads her away from the borders of her personal-cum-professional orbit of Gray's Inn.

The taxi ride to the hospital with a social worker takes time, both in the story and narration. This transition is marked and replete with Fiona's emotional and cultural observations and remembrances. Fiona has time to appreciate the grand views down the Thames, but on the South Bank the tenor of her thoughts and observations take a remarkable turn:

She had a north Londoner's ignorance of and disdain for the boundless shabby tangle of London south of the river. Not a Tube stop to give meaning and relation to a wilderness of villages swallowed up long ago, to sad shops, to dodgy garages interspersed with dusty Edwardian houses and brutalist apartment towers, the dedicated lairs of drug gangs. The pavement crowds, adrift and in alien concerns, belonged to some other, remote city, not her own. [...] Why make a life here? (McEwan 2014: 97)

The otherwise strictly laconic narrator positions Fiona here geographically within the expectations of north Londoners. Within the orbit of the Gray's Inn, Fiona 
regards herself as an impartial and liberal professional, but the trip to the South Bank brings her social prejudices and exclusiveness to the fore. The affluent judge, living within the perimeters of the Inn, does not find much compassion for those creatures whose income does not quite allow them to reside in the more exclusive districts. Eventually, they arrive at "the twenty-six-storey Edith Cavell Wandsworth General." The hospital, a "Japanese-designed circular tower of glass, with cladding of surgical green, built with expensively borrowed money, back in the carefree days of New Labour," (McEwan 2014: 99) is an imagined destination, as there is no Edith Cavell hospital in Wandsworth or anywhere else in London. The invented hospital within the otherwise detailed geography of London provokes Fiona's sour thoughts about the careless spending by the New Labour governments.

Fiona's full attention focuses now on the building, the atmosphere, and the personnel of the hospital. Instead of being on autopilot, she keenly drinks in the environment and lets the space affect her. Fiona is led toward the destination via dramatically changing spaces, from a "glassed-in atrium the height of the entire building" to a fountain, where "New Age music, airy and unmodulating, merged with the sound of tinkling water. The model was, of course, the modern airport" (McEwan 2014: 100). While entering the pediatric oncology department, the change from the High Court atmosphere becomes tangible: "The silence, broken only by an electric hum, and the lack of natural light made it feel like the small hours" (McEwan 2014:101).

The narrator dramatizes Fiona's entrance in the hospital room by using future focalization and looking at the present moment from a vague future point of time. “If Fiona's recollection of stepping into Adam Henry's room was confused, it was because of the disorienting contrasts" (McEwan 2014:102). The reader is made aware of her "confusion" and "disorienting" thoughts when stepping into the room. Fiona's transition from the High Court space into something strange is finalized as she steps in:

There was so much to take in. The place was in semi-darkness but for the focused bright light around the bed. [...] The life-support and monitoring equipment around the bed, the high stands, their feed lines and the glowing screens emanated a watchful presence, almost a silence. But there was no silence, for the boy was already talking to her [...] (McEwan 2014: 103)

Indeed, Fiona is taking all this in; she lets the space influence her. Through a number of geographical and spatial transitions, she finds herself in a strange, exceptional space, one where she is able to depart from her professional scripts and encounter Adam on a more profoundly personal level. She listens to Adam's religious explanations and talks directly to him about his probable blindness and 
death, but she also listens to his poems and music. Adam has started playing the violin; Fiona listens, and finally sings "The Salley Gardens" accompanied by Adam. No doubt, she has a professional agenda, a need to understand Adam as a human being, yet the encounter itself takes place on equal, human terms.

This encounter within this exceptional space brings about significant consequences: Fiona decides against the wishes of Adam and his family, permitting the forced transfusion. This encounter, which is beyond the strict limits of Fiona's profession, conveys a deep personal meaning for Adam, who develops a platonic and possibly romantic attachment to Fiona, and he starts writing her passionate letters. However, after returning to the High Court of Justice and Gray's Inn, Fiona is soon back within the everyday limits of her professional role and does not know how to respond to Adam. What was possible in the hospital is no longer possible at Gray's Inn. Nevertheless, the failure to respond is also a response in itself and has its repercussions.

\section{Transgressing the borders: Newcastle}

Fiona's work includes recurrent round trips to other English cities to preside in cases in situ rather than transporting the parties to London. As such, her trip to Newcastle belongs entirely to her professional domain and she acts within her professional scripts. Arriving in Newcastle, however, arouses paradoxical emotions and expectations: "She had a history with Newcastle and felt at ease here" (McEwan 2014: 151). As a teenager, she used to go there to be with her "favorite cousins" and stay with Uncle Fred, a dentist and "the wealthiest man" she had ever known. The youthful freedom had included, with the "jolly" cousins, clubbing with musicians, cherry brandies, and her first lover. Consequently, Newcastle is a city with particular memories, feelings, and expectations. As a teenager, she escaped the atmosphere around her mother, and now Newcastle offers a temporary respite from the heavy atmosphere of her own home. Newcastle is a permanent reminder of other possible courses of life, a mark of side-shadowing (Morson 1994) that "continued to haunt her whenever she returned, a hazy notion of renewal, of undiscovered potential in another life, even as her sixtieth birthday approached" (McEwan 2014: 153). This concerns not only an emotional relation to a place (Ryan et al. 2016: 39-40); it also involves a character seeing her life and its options differently in different places, with a different horizon of expectations (Koselleck 2004).

History, emotion, and expectations merge in Fiona's exaltation of the space: "It always lifted her spirits to approach the city within sight of Stephenson's High Level Bridge over the Tyne, and to arrive like her excited teenage self, stepping off 
the train at Newcastle Central under the great curved arches of John Dobson's creation...” (McEwan 2014: 152; italics added). Despite these rich and varied emotions, Fiona is travelling in her professional capacity, with the expectation of socializing with other judges and their guests. Her accommodation is at Leadman Hall - a manor house invented for the novel - "set a mile inside its park." Fiona, sitting in "a 1960s Bentley," watches as "she passed a cricket ground, then an avenue of beeches [...]" (McEwan 2014: 153). The judges on the circuit have their accommodation in the hall, grandly built in the Palladian style and serving "mostly as a conference centre and wedding venue" (McEwan 2014: 154). There are twelve bedrooms and a staff of nine to serve the two travelling judges. If the trip to the hospital passed through areas of abject poverty, Leadman Hall and its surroundings radiate upper-class wealth and formality. The whole section from the "reclining" in the Bentley to the dinner party is narrated in declaratory style, not exposing what Fiona feels, thinks, or experiences, with the effect of making her bearing seem increasingly rigid. The evaluation of the scenery, in fact, comes before the whole trip as Fiona muses on the forthcoming "specially maintained lodgings" (McEwan 2014: 146). The class distinctions and her mood are clear:

The bedrooms were far grander than her own, the beds wider, the sheets of finer weave. In happier days, there was, for a securely married woman, guilty and sensuous pleasure in such unshared accommodation. (McEwan 2014:147)

In Fiona's thoughts and evaluation, Leadman Hall provides upper-class luxury and style she was earlier able to enjoy innocently and whole-heartedly. Now she is more self-conscious and merely surveys the park, her rooms, the dining hall, and her company. However, the passage plays with side-shadowing, both by negating ("for securely married woman") and insinuating ("guilty and sensuous pleasures"; "unshared"). Between the upper-class indulgence and formality in front of her colleagues, she is troubled by rather contradictory impulses in "her favourite English city" (McEwan 2014:147).

Fiona's evening program begins with a sherry in the drawing room, with "Four men in dark suits and ties, each holding a gin and tonic," discussing the cases they were working on in Newcastle. At the butler's invitation, Fiona walks "through the double doors to the dining room. The table, which could have seated thirty guests, was set for five at one lonely end" (McEwan 2014: 157). The transfer from Fiona's liberal, teenage Newcastle and its wild atmosphere could hardly be more dramatic. One inconspicuous detail accentuates this change. The novel is set in an exceptionally rainy year, and it is raining through all the major episodes, from the first walk to the concluding Christmas party. The only exception is her arrival in Newcastle. This time, the storm breaks just before the drinks and dinner are served. In this solemn and formal upper-class ambience, the well-dressed 
judges are conversing when Fiona's secretary comes in to inform her of Adam's arrival at the hall.

Their previous meeting, though a diversion from Fiona's ordinary practice and script, had taken place at her own initiative and on her terms, in a neutral site far beyond her professional community. Now, they meet in the former library room of an old, cold mansion, Adam thoroughly wet after running in the rain, with the prestigious guests carrying on their conversation somewhere nearby. Fiona's first reaction is contradictory; she blames herself for not writing to Adam and thus causing the situation, yet, at the same time, she acts as evasively as previously. Their new meeting marks a striking contrast to the direct encounter and personal talk in the hospital. Fiona stays normative, patronizing, and distant, while Adam recounts his quarrels with his parents and the rejection of his religion. Eventually, Fiona insists that Adam tell her why he came to Newcastle. The answer is the confusing "I want to come and live with you" (McEwan 2014: 172).

Of course, this is an outrageous proposal and beyond all canonical expectations. What Adam exactly means by this proposal - what kind of life he imagines remains a secret, since Fiona rejects the proposal categorically, without further discussion. There is no set of expectations that could make the proposal understandable or acceptable to Fiona, who prefers to situate Adam within the standard middle-class scripts of talented youth; she imagines him at university with a plethora of new friends. Does Adam want to be adopted, to start a romantic relationship with the fifty-nine-year-old Fiona in her marital home, or perhaps something else? The proposal threatens Fiona's sanctuary at Gray's Inn: this legal subject is turning dangerously into a human being who insists on crossing the decisive border between home and the professional world. Besides, her home is already a mess.

Fiona never considers seriously the consequences of rescuing Adam's life, of meeting and challenging Adam in the hospital, and thus triggering his departure from his religious community and home. Fiona herself made the relationship personal by transgressing her own professional boundaries and by talking to and singing with Adam in the hospital. Nevertheless, after the meeting, she withdraws to her normal professional role, declining to recognize her personal responsibility in the relationship. Perhaps, on the most basic level, Adam only wants to continue the transformative discussion and contact that had begun in the hospital. There could have been numerous ways of managing such expectations, if considered seriously. Fiona, instead, panics and gives a narrowly technical answer by stating that she only has one spare room for visitors - the room in which Jack had been staying since the beginning their dispute.

After Fiona blocks off all other forms of communication, she perceives the situation from the perspective of stalking and expresses her strong displeasure. 
However proud she was of herself for escaping her mother's control in Newcastle, she orders Adam to contact his mother immediately, and arranges for a taxi to take him back to Newcastle and for a train to return him to the south. Determined as Fiona is in regaining her professional distance and control, the end of Adam's visit restores the ambiguity:

Her intention was to kiss him on the cheek, but as she reached up and he stooped a little and their faces come close, he turned his head and their lips met. She could have drawn back, she could have stepped right away from him. Instead, she lingered, defenseless before the moment. The sensation of skin on skin obliterated any possibility of choice. If it was possible to kiss chastely full on the lips, this was what she did. (McEwan 2014: 174)

After a tense and nervous encounter, after categorically disregarding Adam's wishes to be part of her life, after all the enacted distance, Fiona decides to kiss Adam on the cheek. The kiss expresses Fiona's continual ambiguity in Newcastle. In McEwan's novels, rather small and apparently insignificant events have the capacity to grow and have uncontrollable consequences. The kiss, initiated by herself and not by Adam, signified a dire threat of professional shame and humiliation for her. Did any of her colleagues see the kiss? Are they already gossiping about it? Shocked by these thoughts, she pushes aside all previous regrets and second thoughts about not answering Adam's letters, since now she has her professional integrity and fame to protect. She never considers what Adam had experienced and does not understand his use of the expression "the kiss of Judas" in his last letter (McEwan 2014: 188).

The final events of the novel are set at Gray's Inn during the annual Christmas concert where Fiona is scheduled to accompany her colleague, Mark Berner. The artistic competition among the judges surfaces, and in the form of a geographical comment: "A large minority of Gray's Inn benchers [senior members of the Inn] spent many evenings a year listening in frowning concentration to chamber music over in Marylebone, at Wigmore Hall" (McEwan 2014: 187). The concert goes perfectly, with "The Salley Gardens" being the last piece, and the "Wigmore Hall section" seems to be satisfied. However, just before performing, Fiona learns of Adam's death. His illness had returned, and now Adam as an adult chose to reject the treatment, an act of obvious suicide. Fiona's strategy of professional distance and evasion, the protection of privacy at Gray's Inn, turns out to have dreadful consequences.

The theme of professional failure, and the failure of justice, runs tacitly through the novel. Early in the novel, at the High Court of Justice, Fiona notices Justice Sherwood Runcie, "one of the few, perhaps the only, colleague she preferred to avoid, and not because he was unlikeable" (McEwan 2014: 53). The reason for her evasion was the man's tragically incorrect verdict in the case of two 
siblings dying of sudden infant death syndrome. Fiona is also alert to all the ways her colleagues praise her decisions in the high publicized, dramatic cases. Immediately before starting rehearsals for the Christmas concert, Mark Berner is outraged by a harsh and biased court decision on a rather harmless bar brawl. All of these reflections underscore the fact that the judges do not narrowly "apply the law" by deciding what the law already dictates; rather, they have to reason their cases and weigh up the aspects of cultural canonicity. By discussing and evaluating the cases, by reprimanding and commending the decisions of other judges and barristers, the judges constantly build their own cultural expectations and canonicities. The relevance of this aspect is confirmed in the final concert, where it is none other than the previously reproached Sherwood Runcie who delivers the news about Adam's death.

\section{Toward a geographical narratology}

Ryan et al. write how "as a theoretical and descriptive project, narratology is not the interpretation of individual works but the exploration of regularities found in multiple narrative text" (2016: 207). This is a reasonable point of departure, yet there is still the opposite problem of demonstrating the interpretative power of suggested concepts and perspectives. This article suggests that taking a socionarratological orientation can help decisively in teasing out intended meanings of geographical names, moves, and transgressions. The crucial point has been to study how cultural expectations, contested canonicities, are attached to particular places and images of them. The argument developed in this article is that expectation is a rich and necessary concept in understanding the relevance of geography in fictional and non-fictional narratives.

The perspective of socionarratology also focuses attention on the ways characters themselves experience - observe, feel, taste, reflect - the spaces, exist bodily in varying spaces, and orient themselves with regard to them in the storyworld. In The Children Act, Fiona Maye reacts to her environment in radically different ways during the three narrated trips: the walk, the hospital, and the visit to Newcastle. The walk around Gray's Inn was carried out in such a routine way that her observations did not reveal much of the surrounding. Tracing Fiona's steps as adequately as possible revealed the high walls and iron railings around the Inns and the High Court of Law, intensifying the image of a closely protected and sheltered home and profession.

The concept of expectation, of course, differs significantly from such narratological terms as "focalization" and "narrator". As Koselleck (2004) suggests, it is on a higher, existential level, and resembles the concepts of "time" and "place". 
Expectations can be historical, cultural, political, personal, professional, cognitive, or situational (Tannen 1993), which means that they are inexhaustible. Nevertheless, this in no way signifies the analysis is arbitrary, because it is the role of the characters and narrators to invite the particular and relevant expectations. Indeed, the expectations attached, for instance, to Newcastle in The Children Act do not result from the general history or prototypical image of Newcastle but from the character's own focalized memories.

\section{References}

Bakhtin, M.M. 1981. The dialogic imagination: Four essays by M. M. Bakhtin. Ed. Michael Holquist. Trans. Caryl Emerson \& Michael Holquist. Austin: University of Texas Press.

Baynham, Mike. 2003. Narratives in space and time: Beyond "backdrop" accounts of narrative orientation. Narrative Inquiry 13(2). 347-366.

Baynham, Mike. 2015. Narrative and space/time. In Anna De Fina \& Alexandra Georgakopoulou (eds.), The handbook of narrative analysis, 119-139. Chichester: Wiley Blackwell.

Bruner, Jerome. 1990. Acts of meaning. Cambridge: Harvard University Press.

Bruner, Jerome. 1991. The narrative construction of reality. Critical Inquiry 18. 1-21.

de Certeau, Michel. 1984. The practice of everyday life. Berkeley: University of California Press.

De Fina, Anna. 2003. Crossing borders: Time, space, and disorientation in narrative. Narrative Inquiry 13(2). 367-391.

Fludernik, Monika. 1996. Towards a 'natural' narratology. London \& New York: Routledge.

Frank, Arthur W. 2010. Letting stories breathe. A socio-narratology. Chicago: University of Chicago Press.

Friedman, Susan Stanford. 2005. Spatial poetics and Arundhati Roy's The god of small things. In James Phelan \& Peter J. Rabinowitz (eds.), A companion to narrative theory, 192-205. Malden: Blackwell.

Georgakopoulou, Alexandra. 2003. Plotting the "right place" and the "right time": Place and time as interactional resources in narratives. Narrative Inquiry 13(2). 413-423.

Gray’s Inn 2018. “History.” https://www.graysinn.org.uk/history/the-hall. (accessed 31 Jan. 2018).

Harvey, David. 1989. The condition of postmodernity: An enquiry into the origins of cultural change. Oxford: Blackwell.

Herman, David. 1999. Toward a socionarratology: New ways of analyzing natural language narratives. In David Herman (ed.), Narratologies: New perspectives on narrative analysis, 218-246. Columbus: Ohio State University Press.

Herman, David. 2001. Spatial reference in narrative domains. Text 21(4). 515-541.

Herman, David. 2009. Basic elements of narrative. Malden: Wiley-Blackwell.

Hyvärinen, Matti. 2016. Expectations and experientiality: Jerome Bruner's "canonicity and breach". Storyworlds 9(1). 1-25.

Koselleck, Reinhart. 2004. Futures past: On the semantics of historical time. Trans. Keith Tribe. New York: Columbia University Press. [Original edn, Vergangene Zukunft. Zur Semantik geschichtlicher Zeiten. Suhrkamp Verlag, 1979.]

Labov, William. 1972. Language in the inner city. Oxford: Basil Blackwell. 
Lefebvre, Henri. 1991. The production of space. Trans. Donald Nicholson-Smith. Malden: Blackwell. [Original edn, La production de l'espace. Editions Anthropos, 1974.]

McEwan, Ian. 1978. Cement garden. London: Jonathan Cape.

McEwan, Ian. 1998. Amsterdam. London: Jonathan Cape.

McEwan, Ian. 2005. Saturday. London: Jonathan Cape.

McEwan, Ian. 2010. Solar. New York: Random House.

McEwan, Ian. 2014. The children act. New York: Nan A, Talese/Doubleday.

Morson, Gary Saul. 1994. Narrative and freedom. New Haven: Yale University Press.

Perrino, Sabina. 2015. Chronotopes: Time and space in oral narrative. In Alexandra Georgakopoulou \& Anna De Fina (eds.). The handbook of narrative analysis, 140-159. Chichester: Wiley Blackwell.

Phelan, James. 2007. Experiencing fiction. Judgments, progressions, and the rhetorical theory of narrative. Columbus: The Ohio University Press.

Pickering, Michael. 2004. Experience as horizon. Koselleck, expectation and historical time. Cultural Studies 18(2/3). 271-289.

Ricoeur, Paul. 1981. Narrative time. In W.J.T. Mitchell, (ed.), On narrative, 165-186. Chicago: University of Chicago Press.

Ricoeur, Paul. 1984. Time and narrative. Trans. Kathleen McLaughlin \& David Pellauer. Vol. 1. Chicago \& London: University of Chicago Press.

Ryan, Marie-Laure, Kenneth Foote \& Maoz Azaryaahu. 2016. Narrating space/Spatializing narrative. Where narrative theory and geography meet. Columbus: The Ohio State University Press.

Scott, Joan W. 1998. Experience. In Sidonie Smith \& Julia Watson (eds.), Women, autobiography, theory: A reader, 57-71. Madison: The Wisconsin University Press. [Original edn, The Evidence of Experience, Critical Inquiry 17 (Summer 1991).]

Tannen, Deborah. 1993. What's in a frame? In Deborah Tannen. Framing in discourse, 14-56. Oxford: Oxford University Press. 